American Journal of Applied Sciences 7 (1): 120-126, 2010

ISSN 1546-9239

(C) 2010 Science Publications

\title{
Exploring Critical Determinants in Deploying Mobile Commerce Technology
}

\author{
${ }^{1}$ Saad G. Yaseen and ${ }^{2}$ Suleiman Zayed \\ ${ }^{1}$ Department of Management of Information System, \\ Al-Zaytoonah University of Jordan, Jordan \\ ${ }^{2}$ Department of Management of Information System, \\ Arab Academy for Banking and Financial Science, Jordan
}

\begin{abstract}
Problem statement: The research's problem lies in the fact that deploying m-commerce technology in Jordan represent the first serious trail to understand and explore the critical determinants that affect deploying mobile commerce technology. Approach: This research applied TAM model using the following variables: Perceived trust, perceived usefulness, perceived ease of use, social and cultural values and economic issues to explore determinants. Results: The result of the distributed 210 questionnaires to mobile commerce users in Amman Stock Exchange (Brokers and Investors) and 179 were returned correct and studied, reveal that perceived trust, perceived usefulness, perceived ease of use, social and cultural values have significant association with intention to deploy mobile commerce technology while economical issue is not significant. Conclusion: The results of the research indicate that TAM have capability in exploring critical determinants that affecting the intention to deploy mobile commerce technology in Jordanian marketplace, therefore, further studies are recommended to explore the critical determinants of deploying mobile commerce technology in other economic sectors.
\end{abstract}

Key word: Technology acceptance models, mobile commerce information and communication technology

\section{INTRODUCTION}

Deploying mobile commerce technology is a very difficult issue, because m-commerce services are increasingly large and enhancing enterprises' abilities to offer mobile commerce services anytime and anywhere. However, studies on the use and adoption of mobile services indicate that traditional acceptance models need to be extended and modified when applied to mobile commerce technology. The need for exploring critical determinants that actually affect deploying mobile commerce is essential due to explosive growth and penetration of mobile devices worldwide in general and in Jordan in particular due to technological advances, regulatory changes and market demand, which prompted the willingness of the innovators and the organizations to deploy $\mathrm{m}$ commerce. The significance of the research lies in the fact that deploying mobile commerce technology in Jordan represents the first serious trial to understand and explore the critical determinants that affect deploying mobile commerce technology and to understand the social phenomenon accompanied to the spread of mobile commerce.
This study aims to present an in-depth study of Mcommerce adoption, analyzing the variables which influence the decision maker's to determine the influence of relations with the characteristics of mobile device and the applications that can be obtained and to identify key drivers of future M-commerce intention in Amman Stock Exchange.

Background and related research: The Technology Acceptance Model (TAM) can be traced back to the doctoral dissertation of Davis (1989). Davis et al. (1989) looked at user acceptance of computer technology by comparing two models those of TAM and TRA (Ajzen, I., 1991; Ajzen and Fishbein, 1980). TAM is tailored to IS context and was designed to predict IT acceptance and usage. TAM is based on the theory of reasoned action and theory of planned behavior Ajzen (1991). Chau and $\mathrm{Hu}$ (2002) decomposed perceived usefulness into two partsperceived near term usefulness and perceived long term usefulness and he found that perceived near term usefulness had the most significant relation with the intention to use a technology, followed by perceived long term usefulness variable. In adoption research, the

Corresponding Author: Saad G. Yaseen, Department of Management of Information System,

Al-Zaytoonah University of Jordan, Jordan 
technology acceptance model focuses on the attitudinal explanations of intention to use a specific technology or service. Davis et al. (1989) According to this model, both perceived usefulness and ease of use influence the attitude of individuals towards the use of technology, while attitude and perceived usefulness of the technology predict the individual's behavior to use the technology. This model has been widely used over the past decade as a means of predicting user's intention to use new technologies. There TAM could be useful in predicting user's intention to adopt new services and applications. Numerous empirical studies have provided support for the proposition that perceived usefulness is the primary predictor of information technology usage (Davis et al., 1989; 1992; Gefen et al., 2003; Igbaria et al., 1997; Wang et al., 2003; Ikart, 2005; Venkatesh and Davis, 1996; Venkatesh, 2000; Venkatesh et al., 2000). O'Cass and Fenench (2003) argue that TAM is appropriate for research areas in electronic commerce applications since electronic commerce is based on computer technology. As scholars indicate that M-commerce is an extension of e-commerce, it is thus justifiable to extend TAM to examine consumer intention to adopt behavior. Unifying the various models of IT acceptance was completed by (Chau and Hu, 2002; Davis, 2001) and wherein they integrated the elements of eight prominent models. The UTAUT aims to explain user intentions to use an IS and subsequent usage behavior. The theory holds that four key constructs (performance expectancy, effort expectancy, social influence and facilitating conditions) are direct determinants of usage intention and behavior (Venkatesh and Speier, 1999). Gender, age, experience and voluntariness of use are posited to mediate the impact of the four key constructs on usage intention and behavior (Venkatesh and Speier, 1999). Moreover, Prior studies have extended TAM with new constructs such as perceived playfulness, perceived enjoyment and others. It is also widely recognized that subjective norms and perceived behavioral control are important for understanding and predicting intentions and behavior in specific contexts (Chan et al., 2004; Chismar and Patton, 2003; Klopping and McKinney 2004; Luarn and Lin, 2005; Triandis et al., 1980; Venkatesh et al., 2003; Leung et al., 2003; Sekaran, 1992; Shih, 2004). Based on the literature discussed and relations hypothesized between different variables, we constructed a research model shown in Fig. 1, this model is used to test how people and organizations deal with new technology, accept, resist or reject and potentially influence an individual and organizational adoption decision regarding mobile commerce, because mobile commerce technology is considered the new wave of IT. An extended version of the technology acceptance model was employed to determine factors such as trust, perceived usefulness, perceived ease of use, social and cultural values, economic issues that influence a decision maker intention to adopt this type of technology in doing business.

Perceived trust: Trust is considered as a key factor for succeeding in doing e-commerce and $\mathrm{m}$-commerce, trust is major enabler of mobile device transactions because of a natural human need to believe in the social surrounding of the virtual environment Perceived Usefulness: "The degree to which a person believes that using a particular system would enhance his or her job performance, by ubiquity, convenience localization, personalization, device optimization" (Davis et al., 1989).

Perceived ease of use: "The degree to which a person believes that using a particular system would be free of physical and mental effort" (Davis et al., 1989), freedom from difficulty and effort.

Social and cultural trends: Social factors are defined as "an individual's internalization of the reference group's subjective culture and specific interpersonal agreements that the individual has made with others, in specific social situations" (Venkatesh and Morris, 2000). Thus, social factors try to capture the congruency between social norms and individual beliefs and how the human part of an individual's environment affects one in performing a specific behavior. Social factors are defined as "an individual's internalization of the reference group's subjective culture and specific interpersonal agreements that the individual has made with others, in specific social situations" (Venkatesh and Morris, 2000).

Economic issues: Economics is the social science that studies "mankind in the everyday business of life" (Marshall).

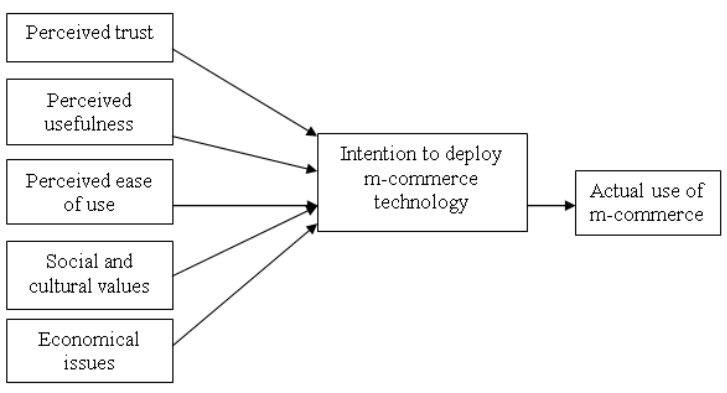

Fig. 1: The proposed model. Source: Prepared by the researchers 
Am. J. Applied Sci., 7 (1): 120-126, 2010

Intention: Intention is an indication of a person's readiness to perform a given behavior and it is considered to be the immediate antecedent of behavior.

Hypothesis: To accomplish the objectives of this research, the following hypothesis will be tested:

H1: Perceived Trust have direct significant effect on $\mathrm{m}$-commerce users' intention to deploy $\mathrm{m}$ commerce technology

H2: Perceived Usefulness have direct significant effect on m-commerce users' intention to deploy $\mathrm{m}$ commerce technology.

H3: Perceived ease of use has significant effect on mcommerce users' intention to deploy m-commerce technology

H4: Social and cultural values have direct significant effect on the m-commerce users' intention to deploy m-commerce technology

\section{MATERIALS AND METHODS}

In this study brokers and mobile commerce technology users from Amman stock exchange are chosen to conduct study.

Reliability: The results of reliability show that Alpha Cronbach's was 0.7098 for trust variable, 0.663 for usefulness variable, 0.703 for ease of use, 0.7636 for social and cultural values, 0.9033 for economical issues, 0.834 for intention and 0.8184 for actual use (Table 1). The values of Alpha Cronbach's for each variable were higher than 0.6 , which is the acceptable value for such research (Thompson and Davis, 2000).

Model validity: In this study, summative scale technique was used to merge several sub factors into a single factor by calculating average scale of each factor (Heck, 2004). Factor Analysis was used applying Varimax procedure and Eigen value more than one. When the loading factor is more than 0.40 (Heck, 2004), then the paragraph is valid to measure the variable.

Eigen value determines the accepted factors, Kaiser-Meyer-Olkin (KMO) measured the fitness of using factor analysis for this data. The value of KMO was more than 0.50 reflecting the fitness of factor analysis for this data, KMO measure provides a means to asses the extent to which the variables of the model belong together. Loading factor and explained variance were used to measure the validity of each construct as shown in Table 1. The respondents were closed in their predominantly positive intention toward using mobile commerce technology and actual use.
Table 1: Construct validity of research variables

\begin{tabular}{|c|c|c|c|c|c|}
\hline Variable & $\begin{array}{l}\text { Loading } \\
\text { factor }\end{array}$ & $\begin{array}{l}\text { Explained } \\
\text { variance }\end{array}$ & $\mathrm{KMO}$ & $\begin{array}{l}\text { Eigen } \\
\text { value }\end{array}$ & $\begin{array}{l}\text { Cronbach's } \\
\text { Alpha }\end{array}$ \\
\hline Trust & $\begin{array}{l}0.880 \\
0.863 \\
0.606 \\
0.279\end{array}$ & 49.086 & 0.597 & 1.963 & 0.7100 \\
\hline Usefulness & $\begin{array}{l}0.736 \\
0.799 \\
0.747 \\
0.512\end{array}$ & 50.023 & 0.671 & 2.001 & 0.6630 \\
\hline Ease of Use & $\begin{array}{l}0.747 \\
0.760 \\
0.727 \\
0.682\end{array}$ & 53.273 & 0.616 & 2.131 & 0.7030 \\
\hline $\begin{array}{l}\text { Social and } \\
\text { cultural } \\
\text { issues }\end{array}$ & $\begin{array}{l}0.772 \\
0.871 \\
0.801 \\
0.614\end{array}$ & 59.334 & 0.737 & 2.373 & 0.7636 \\
\hline $\begin{array}{l}\text { Economical } \\
\text { issues }\end{array}$ & $\begin{array}{l}0.839 \\
0.899 \\
0.871 \\
0.893 \\
0.355\end{array}$ & 63.866 & 0.847 & 3.193 & 0.9033 \\
\hline Intentions & $\begin{array}{l}0.841 \\
0.816 \\
0.830 \\
0.783\end{array}$ & 66.908 & 0.794 & 2.676 & 0.8340 \\
\hline Actual use & $\begin{array}{l}0.792 \\
0.813 \\
0.812 \\
0.763 \\
0.640\end{array}$ & 58.748 & 0.770 & 2.937 & 0.8180 \\
\hline
\end{tabular}

\section{RESULTS}

To accomplish the objectives of this study, hypotheses should be tested to find out the relationship between variables. These tests as follow:

\section{First hypothesis:}

H1: Trust will have direct significant effect on mcommerce users' intention to deploy m-commerce technology.

The testing result of the analysis is as follow:

$\mathrm{Y}=1.963+0.420 \mathrm{X}$

$(\mathrm{t}=5.854$ with significance $=0.001) \quad(\mathrm{t}=1.96$ tabulated)

$\mathrm{R}^{2}=0.113$

$\mathrm{F}=22.50(\mathrm{~F}=2.34$ tabulated $)$

Where:

$\mathrm{Y}=$ Intention to deploy $\mathrm{m}$-commerce technology

$\mathrm{X}=$ Trust of using $\mathrm{m}$-commerce technology

Perceived trust explained $11.3 \%$ of the effect on the user's intention of deploying mobiles commerce technology. The Trust effect on the user's intention to 
deploy mobile commerce was significant with probability $0.001(<0.05)$.

\section{Second hypothesis:}

H2: Perceived usefulness has significant effect on the intention of mobile commerce user's to deploy mcommerce technology.

The testing result of the analysis is as follow:

$\mathrm{Y}=1.804+0.471 \mathrm{X}$

$(\mathrm{t}=5.854$ with significance $=0.001)(\mathrm{t}=1.96$ tabulated)

$\mathrm{R}^{2}=0.162$

$\mathrm{F}=34.72(\mathrm{~F}=2.34$ tabulated $)$

Where:

$\mathrm{Y}=$ Intention to deploy $\mathrm{m}$-commerce technology

$\mathrm{X}=$ Perceived usefulness to deploy m-commerce technology

Perceived usefulness explained $16.2 \%$ of the effect on the user's intention of deploying mobile commerce technology. The effect of usefulness is significant with values 0.001 . This means that perceived usefulness has considerable effect on user's intention of deploying mcommerce.

\section{Third hypothesis:}

H3: Perceived ease of use has a significant effect on the $\mathrm{m}$-commerce users' intention to deploy m-commerce technology. The testing result is as follows:

$$
\begin{aligned}
\mathrm{Y}= & 2.007+0.413 \mathrm{X} \\
(\mathrm{t}= & 5.296 \text { with significance }=0.001)(\mathrm{t}=1.96 \\
& \text { tabulated }) \\
\mathrm{R}^{2}= & 0.137 \\
\mathrm{~F}= & 28.05(\mathrm{~F}=2.34 \text { tabulated })
\end{aligned}
$$

Where:

$\mathrm{Y}=$ Intention to deploy m-commerce technology

$\mathrm{X}=$ Perceived ease of use to deploy $\mathrm{m}$-commerce technology

The increase of perceive ease of use by one unit will improve the intention of deploying mobile commerce technology by 0.413 . This means that there is a positive relationship between perceive ease of use on the user's intention to deploy mobile commerce. This relation is highly significant with probability value equal 0.001 ; ease of use explains $13.7 \%$ of the user's intention to deploy mobile commerce technology.

\section{Fourth hypothesis:}

H4: Social and cultural values have significant effect on the m-commerce users' intention to deploy mcommerce technology.
The testing result is as follows:

$\mathrm{Y}=2.460+0.301 \mathrm{X}$

$(\mathrm{t}=2.697$ with significance $=0.008)(\mathrm{t}=1.96$ tabulated)

$\mathrm{R}^{2}=0.039$

$\mathrm{F}=7.271(\mathrm{~F}=2.34$ tabulated $)$

Where:

$\mathrm{Y}=$ Intention to deploy m-commerce technology

$\mathrm{X}=$ Perceived social and cultural values that affect the user's intention of deploying mobile commerce technology

Perceive social and cultural values have the lowest effect on the user's intention of deploying mobile commerce technology. This is resulted of the low perceive of the social and cultural values. The increase of perceive of social and cultural values will affect the intention of deploying mobile commerce technology significantly $(\mathrm{p}<0.01)$, despite the low explanation of this variable for the intention of deploying mobile commerce.

\section{Fifth hypothesis:}

H5: Economical issues have a significant effect on mcommerce intention to deploy m-commerce technology. The testing result is as follows:

$$
\begin{aligned}
\mathrm{Y}= & 3.298+0.069 \mathrm{X} \\
(\mathrm{t}= & 0.782 \text { with significance }=0.435)(\mathrm{t}=1.96 \\
& \text { tabulated }) \\
\mathrm{R}^{2}= & 0.003 \\
\mathrm{~F}= & 0.612(\mathrm{~F}=2.34 \text { tabulated })
\end{aligned}
$$

Where:

$\mathrm{Y}=$ Intention to deploy m-commerce technology

$\mathrm{X}=$ Perceived economical issues on the user's intention to deploy m-commerce technology

The economical issues do not affect the user's intention of deploying mobile commerce because brokers and investors did not find that deploying of mobile commerce technology is related to economical issues.

\section{Sixth hypothesis:}

H6: Intention to deploy m-commerce technology has a significant effect on the actual use of m-commerce users.

The testing result is as follows:

$\mathrm{Y}=2.044+0.409 \mathrm{X}$ 
$(\mathrm{t}=6.091$ with significance $=0.001)(\mathrm{t}=1.96$ tabulated)

$\mathrm{R}^{2}=0.173$

$\mathrm{F}=37.105(\mathrm{~F}=2.34$ tabulated $)$

Where:

$\mathrm{Y}=$ Actual use of $\mathrm{m}$-commerce technology

$\mathrm{X}=$ Intention to deploy $\mathrm{m}$-commerce technology

User's intention to deploy mobile commerce technology affects positively the actual use of mobile commerce. This effect is positive and significant $(p<0.001)$. The change in the user's intention explains $17.73 \%$ of the change in the actual use of mobile commerce.

\section{DISCUSSION}

In most cases, mobile commerce technology users' adoption was much slower than originally anticipated, this trend is often attributed to technological limitations, security issues and significant economic investments associated with implementing mobile commerce technology (Deans, 2002). Despite those issues that must be overcome, the main reason for the lack of mobile commerce users adoption stems from the fact that current mobile applications fail to deliver a sufficiently compelling value proposition to corporate decision makers (Igbaria, 1993). The results of this study found that brokers and investors are not completely satisfied with the benefits achieved by deploying mobile commerce which similar to Deans (2002) and Heck (2004) results.

The results of the first hypothesis show that perceived of trust has no significant effect on mobile commerce users' intention to deploy mobile commerce technology. The results of the second hypothesis when applying multiple regression show that perceived usefulness has positive relationship with the user's intention to deploy mobile commerce technology, The results of our research is consistent with many previous studies that focused on the acceptance and use of new technology and have provided support for the proposition that perceived usefulness is considered as one of the primary predictor of mobile commerce technology usage (Davis et al., 1989; 1992; Gefen et al., 2003; Igbaria et al., 1997; Wang et al., 2003). The results of the third hypothesis testing show that perceived ease of use has a more powerful and consistent predictor than perceived usefulness towards user's intention to deploy mobile commerce technology. The results of our study is consistent with many previous studies that focused on the acceptance and use of new technology and the result of their studies demonstrated that perceived ease of use has a positive correlation with behavioral intention (Davis et al., 1989; Gefen et al., 2003; Wang et al., 2003). A possible explanation of these findings is that the stability of the legislative environment for economic issues, in addition to the interest rate, the cost of transaction and the income of the mobile commerce users affects their planning to deploy m-commerce technology in Jordanian environment. The results of the sixth hypothesis show that user's intention to deploy mobile commerce technology in Jordanian market place has positive relationship with the actual use of mobile commerce. These results are consistent with many previous studies that focused on the acceptance and use of new technology (Compeau and Higgins, 1995; Venkatesh and Davis, 2000).

\section{CONCLUSION}

The current research represents one of the first empirical efforts for eliciting, analyzing, specifying and exploring critical determinants such as: (Perceived trust, perceived usefulness, perceived ease of use, social and cultural values and economical issues) on the user's intention of deploying mobile commerce technology on the Jordanian marketplace, by incorporating variables from technology acceptance/adoption models. The finding of this study are supportive of the fact that more usefulness and more of ease of use of mobile commerce technology are more likely affect the user's intention of mobile commerce technology adoption. This indicates that mobile commerce is perceived to be high in instrumentality leading higher acceptance/adoption rate. The result in coincide of other studies and the link between those two determinants in agreement with the prior study (Davis et al., 1989).

\section{REFERENCES}

Ajzen, I., 1991. The theory of planned behavior. Org. Behav. Hum. Dec. Process., 50: 179-211.

Ajzen, I. and M. Fishbein, 1980. Understanding Attitudes and Predicting Social Behavior. PrenticeHall, New Jersey.

Chan, S. Cheung and L.T. Ming, 2004. Understanding internet banking Adoption and use behavior: A Hong Kong perspective. J. Global Inform. Manage., 12: 21-43. http://www.infoscionline.com/downloadPDF/pdf/ITJ2577_ZN6GJ6A 42T.pdf 
Chau, P.Y.K. and P.J. Hu, 2002. Examining a model of information technology acceptance by individual professionals: An exploratory study. Manage. Inform. Syst., 18: 191-2295.

Chismar W.G. and S.W. Patton, 2003. Does the extended technology acceptance model apply to physicians? Proceeding of the 36th Hawaii International Conference on System Sciences, Hawaii, Jan. 6-9, IEEE Computer Society, Washington, DC., USA., pp: 1-160.

http://portal.acm.org/citation.cfm?id=821635

Compeau, D.R. and C.A. Higgins, 1995b. Computer self-efficacy: Development of a measure and initial test. MIS Q., 19: 189-211.

Davis, F.D., 1989. Perceived usefulness, Perceived ease of use and user acceptance of information technology. MIS Q., 13: 319-339. http://www.citeulike.org/user/njyo/article/1434179

Davis, F.D., R.P. Bagozzi and P.R. Warshaw, 1989. User acceptance of computer technology: A comparison of two theoretical models. Manage. Sci., 35: 982-1002.

Davis, F.D., R.P. Bagozzi and P.R. Warshaw, 1992. Extrinsic and intrinsic motivation o use computers in the workplace. J. Applied Soc. Psychol., 22: 1111-1132.

Davis, G.B., 2001. Anytime/anyplace computing and the future of the knowledge work. Commun. ACM., 45: 67-73.

Deans, C., 2002. Global trends and issues for mobile/wireless commerce. Proceeding of the 8th Americas Conference on Information Systems, (AMCIS'02), AIS Electronic Library, pp: 2395-2402. http://aisel.aisnet.org/cgi/viewcontent.cgi?article $=1$ $686 \&$ context $=$ amcis 2002

Gefen, D., E. Karahanna and D.W. Straub, 2003. Trust and TAM in online shopping: An integrate model. MIS Q., 27: 51-90.

Heck, M., 2004. Mobilizing the Enterprise. InfoWorld, 26: 24-26.

Igbaria, M., 1993. User acceptance of microcomputer technology: An empirical test. Omega Int. J. Manage. Sci., 21: 73-90.

Igbaria, M., N. Zinatelli, P. Cragg and A.L.M. Cavaye, 1997. Personal computing acceptance factors in small firms: A tructural equation model. MIS Q., 21: 279-305.

Ikart, E.M., 2005. Executive information systems and the top level officer's roles: An exploratory study of user behavior model and lessons learnt. Aust. J. Inform. Syst., 13: 78-100.

Klopping, M.I. and McKinney, 2004. Extending the technology acceptance model and task technology fit model to consumer e-commerce. Inform. Technol. Learn. Perform. J., 22: 35-48.
Leung, C., Y. Chan and C. Chan, 2003. Analysis of mobile commerce market in Hong Kong Proceedings of the 5th International Conference on Electronic Commerce, Sept. 30-Oct. 3, ACM Press, USA., pp: 408-412. http://portal.acm.org/citation.cfm?id=948058

Luarn, P. and H.H. Lin, 2005. Towards an understanding of the behavioral intention to use mobile banking. Comput. Hum. Behav., 21: 873-891. DOI: 10.1016/j.chb.2004.03.003

O'Cass, A. and T. Fenench, 2003. Web retailing adoption: Exploring the nature of internet users Webretailing behavior. J. Retail. Consum. Serv., 10: 81-94.

Sekaran, U., 1992. Research Methods for Business: A Skill Building Approach. 2nd Edn., John Wiley and Sons, Inc.

Shih, P.H., 2004. An empirical study of predicting user acceptance of e-shopping on web. Internet Manage., 41: 351-568.

Thompson Venkatesh, V. and F.D. Davis, 2000. A theoretical extension of the technology acceptance model: Four longitudinal field studies. Manage. Sci., 45: 186-204.

Triandis C. Kagitcibasi and G. Yoon, 1980. Individualism and Collectivism: Theory, Method and Applications. Thousand Oaks, CA., Sage.

Venkatesh, V., M. Morris, G. Davis and F. Davis, 2003. User acceptance of information technology: Towards a unified view. MIS Q., 27: 425-477.

Venkatesh, V. and F.D. Davis, 1996. A model of the antecedents of perceived ease of use development and test. Dec. Sci., 27: 451-481. DOI: 10.1111/j.1540-5915.1996.tb01822.x

Venkatesh, V., 2000. Determinants of perceived ease of use: Integrating perceived behavioral control, computer anxiety and enjoyment into the technology acceptance model. Inform. Syst. Res., 11: 342-365.

Venkatesh, V. and F.D. Davis, 2000. A theoretical extension of the technology acceptance model: Four longitudinal field studies. Manage. Sci., 46: 186-204.

Venkatesh, V. and M.G. Morris, 2000. Why don't men ever stop to ask for directions? Gender, Social influence and their role in technology acceptance and usage behavior. MIS Q., 24: 115-139.

Venkatesh, V. and C. Speier, 1999. Computer Technology training in the workplace: A longitudinal investigation of the effect of the mood. Org. Behav. Hum. Dec. Process., 79: 1-28. 
Venkatesh, V., M.G. Morris and P.L. Ackerman, 2000. A longitudinal field investigation of gender differences in individual technology adoption decision making processes. Org. Behav. Hum. Dec. Process., 83: 33-60.
Wang Y. Shun, Wang Y. Min, Lin H. Hsin and I.T. Tang, 2003. Determinants of user acceptance of internet banking: An empirical study. Int. J. Serv. Ind. Manage., 14: 501-519. 